\section{Are environmental pollutants risk factors for low birth weight?}

\author{
Os poluentes ambientais são fatores de risco para \\ o baixo peso ao nascer?
}

\section{Abstract}

The aim of this study was to assess the association between prenatal exposure to air pollutants and low birth weight in a medium-sized city. An ecological study was performed, using live birth data from São José dos Campos, São Paulo State, Brazil. The environmental data were obtained from the São Paul State Environmental Agency. The study included full-term newborns whose mothers were 20 to 34 years of age and had at least a complete high school education, seven or more prenatal visits, singleton pregnancy, and vaginal delivery, in order to minimize potential confounding from these variables. Logistic regression was used to estimate the effect of each pollutant. Low birth weight was defined as less than 2,500g. The sample included a total of 2,529 data from 2001 that met the inclusion criteria (25.6\% of the total). We identified 99 newborns (3.95\% of the sample) with low birth weight, and the pollutants sulfur dioxide and ozone were associated with low birth weight. The final model was $\pi(x)$ $=-1.79+1.30\left(\mathrm{SO}_{2}\right)+1.26\left(\mathrm{O}_{3}\right)$. Thus, sulfur dioxide and ozone were identified as risk factors for low birth weight in a medium-sized city in Southeast Brazil.

Ozone; Sulfur Dioxide; Environmental Pollutants; Low Birth Weight
Luiz Fernando C. Nascimento ${ }^{1}$

Douglas A. Moreira 1

\section{Introduction}

There is extensive evidence that air pollution affects human health, especially that of children. These effects have become the object of various studies in the last ten years, including in Brazil 1,2,3,4. The studies have focused on respiratory disorders, birth defects, and intrauterine mortality.

Sulfur dioxide $\left(\mathrm{SO}_{2}\right)$ is a respiratory irritant absorbed in the upper airways and that deposits in the more distal lung areas and lung parenchyma. It leads to a decrease in lung function and even pulmonary necrosis in animals. The main sources are industries that use coal and petroleum products and motor vehicles that run on fossil fuels.

The ozone $\left(\mathrm{O}_{3}\right)$ near the Earth's surface results from photochemical reactions with other pollutants, like nitrogen oxides, with solar radiation. It can reach the more distal areas of the lungs and produce inflammation and decreased lung function. Ozone is a powerful oxidant, participating in intra and extracellular reactions with the involvement of important metabolic enzymes. It accounts for the aggravation of preexisting respiratory disorders and an increase in hospitalizations and emergency visits due to respiratory illnesses.

Particulate matter with an aerodynamic diameter less than $10 \mu\left(\mathrm{PM}_{10}\right)$ comes mainly from burning of fossil fuels 5 , with a half-life ranging 
from several days to years. $\mathrm{PM}_{10}$ is associated with an increase in respiratory symptoms and illnesses in children, including increased incidence and aggravation of asthma 5 .

Bobak 6 \& Wang et al. 7 identified $\mathrm{SO}_{2}$ and total suspended particulate (TSP) as associated with low birth weight. In Brasil, Medeiros \& Gouveia 8 found an association between low birth weight and the pollutants $\mathrm{CO}, \mathrm{PM}_{10}$, and $\mathrm{NO}_{2}$, while Junger \& Leon 9 found no significant association between low birth weight and the pollutants $\mathrm{PM}_{10}$, ozone, nitrogen oxide $\left(\mathrm{NO}_{2}\right)$, carbon monoxide (CO), or $\mathrm{SO}_{2}$.

Studies from a literature review by Šrám et al. 10 identify these pollutants as potentially harmful to birth weight, but did not conclusively identify during which period the fetus is most susceptible to them. Research on the most critical period assumes that the fetus and newborn are more sensitive than adults to environmental pollutants, and that major fetal weight gain occurs during the $28^{\text {th }}$ and $36^{\text {th }}$ week of gestational age 11 .

The current study aimed to assess the association between prenatal exposure to sulfur dioxide, ozone, and particulate matter and low birth weight in São José dos Campos, a medium-sized city in Southeast Brazil, in 2001.

\section{Methodology}

This was an ecological, time-series study of data from São José dos Campos, located in the Paraíba Valley in the State of São Paulo, 90km from the city of São Paulo and $320 \mathrm{~km}$ from the city of Rio de Janeiro. The population is approximately 550 thousand, with a territory of $1,100 \mathrm{~km}^{2}$ (some $360 \mathrm{~km}^{2}$ of which is urban). Altitude is $600 \mathrm{~m}$ above sea level, and the city is located at $23^{\circ} 11^{\prime}$ South and $45^{\circ} 53^{\prime}$ 'West. Average low temperature is $14^{\circ} \mathrm{C}$ and average high $26^{\circ} \mathrm{C}$. The municipality has some 1,100 industrial establishments, mainly automobile assembly, pharmaceutical, and aircraft factories and an oil refinery.

Data on birth weight were obtained from the website of the São Paulo State Health Department, for 2001. The sample included newborns whose mothers were 20 to 34 years of age and had at least a complete high school education (11 years of schooling or more), at least seven prenatal visits, vaginal delivery, singleton pregnancy, and childbirth at 37 to 41 weeks of gestational age. The criteria aimed to eliminate or minimize confounding between these variables and the effects of pollutants on birth weight. Low birth weight was defined as less than $2,500 \mathrm{~g}$.

Daily data on the pollutants $\mathrm{SO}_{2}, \mathrm{O}_{3}$, and $\mathrm{PM}_{10}$ were obtained from the office of the São Paulo
State Environmental Agency (CETESB) in São José dos Campos, which has two environmental monitoring stations located $3 \mathrm{~km}$ apart, inside the city limits. For all the pollutants, data collection started immediately after midnight and covered a 24-hour period, quantifying the measurements in $\mu \mathrm{g} / \mathrm{m}^{3}$. Daily measurements were considered for each pollutant. The respective techniques were: beta monitor for $\mathrm{PM}_{10}$, coulometry for $\mathrm{SO}_{2}$, and chemiluminescence for $\mathrm{O}_{3}$.

Databanks were constructed with accumulated data on quarterly exposure to each pollutant, so as to allow for a cumulative effect and to estimate the dose-response effect for each pollutant and the outcome. For each day analyzed for the occurrence of low birth weight events, we considered the total values for the previous 90 days for each pollutant. Thus, for a low birth weight infant born on January 1, 2001, we associated the total for each pollutant from October 3, 2000, and December 31, 2000, to analyze these cumulative 90-day effects, and so on.

We did not take the seasons of the year into account, since the temperature variation between the hottest and coldest seasons is negligible in São José dos Campos, nor did we include altitude, since the city is flat and does not have any rises in its terrain. Correlations with the pollutants were analyzed with the Pearson correlation coefficient.

The variable "low birth weight" was analyzed as discrete (by counting), and the number of events was reported for each day studied in the year 2001. Subsequently, the values were considered either zero (absence of low birth weight events) or one (presence of any number of low birth weight events). The presence or absence of low birth weight was estimated according to the odds ratio (OR) for each quartile in ordinal and increasing fashion. The $25^{\text {th }}$ percentile was taken as the reference.

We estimated the odds of low birth weight according to the target pollutants, with the first quartile as the reference (0) and the others grouped in the risk group (1) according to the logistic regression technique. This approach was used for the 90-day effects. The final model was elaborated using the stepwise forward technique, and the pollutants with $\mathrm{p}<0.20$ entered the model. Those with $\mathrm{p}<0.05$ remained in the final model. Statistical significance was set at $5 \%$ in this study.

\section{Results}

The sample included a total of 2,529 data from São José dos Campos for the year 2001 and that 
met the inclusion criteria $25.6 \%$ of the births from that year). Mean birth weight was 3,201.7g ( standard deviation $=423.2 \mathrm{~g}$ ).

The study identified 99 low birth weight newborns (3.95\% of the sample). Table 1 shows the mean values for the pollutants and the respective standard deviations in $\mu \mathrm{g} / \mathrm{m}^{3}$, according to the respective time period (90 days), together with the minimum and maximum values.

The pollutants $\mathrm{SO}_{2}$ and $\mathrm{PM}_{10}$ were highly and positively inter-correlated $(r=0.88)$, and both showed a negative correlation with ozone $(\mathrm{p}<0.01)$.

Analyzing the pollutants by quartiles, low birth weight was significantly associated with $\mathrm{SO}_{2}$ exposure in the second and third quartiles. The $\mathrm{PM}_{10}$ quartile values were not associated with low birth weight. For the third quartile, ozone showed borderline statistical significance, with an increase of nearly $100 \%$ in the odds of low birth weight (Table 2).

The final model obtained the following OR values and standard deviations: for $\mathrm{SO}_{2}, \mathrm{OR}=$ 1.30 (95\%CI: 1.02-1.65, $\mathrm{p}=0.034$ ) and for $\mathrm{O}_{3}, \mathrm{OR}=$ 1.26 (95\%CI: $1.00-1.58, \mathrm{p}=0.050$ ) (Table 3 ). Thus the final logistic regression model was $\pi(\mathrm{x})=-1.79$ $+1.30\left(\mathrm{SO}_{2}\right)+1.26\left(\mathrm{O}_{3}\right)$.
Levels of pollutants $\mathrm{SO}_{2}$ and $\mathrm{O}_{3}$ above those in the first quartile (reference) showed fivefold odds of low birth weight in this sample.

\section{Discussion}

The findings from this study, conducted in a medium-sized city, São José dos Campos, showed an association between the air pollutants sulfur dioxide and ozone and low birth weight. This association was demonstrated by including data from newborns whose mothers were 20 to 34 years of age and had at least a complete high school education, at least seven prenatal visits, vaginal delivery, singleton pregnancy, and gestational age 37 to 41 weeks at delivery. These inclusion criteria served to control for known potential confounders of low birth weight.

The current study thus fills a gap in research on the effects of air pollutants on birth weight in medium-sized cities in Brazil.

The study assumed that the concentrations of pollutants were homogeneous throughout the city and that all the mothers were equally exposed to the pollutants during the target period. In addition, since these were normal pregnan-

Descriptive analysis of each pollutant considering exposure during the 90 days prior to birth, in $\mu \mathrm{g} / \mathrm{m}^{3}$. São José dos Campos, São Paulo State, Brazil, 2001 *.

\begin{tabular}{lccc}
\hline & Mean (SD) & Minimum & Maximum \\
\hline $\mathrm{SO}_{2}$ & $535.6(103.8)$ & 364.6 & 744.9 \\
$\mathrm{PM}_{10}$ & $3,165.7(1,028.2)$ & $2,000.3$ & $5,140.2$ \\
$\mathrm{O}_{3}$ & $6,095.2(500.9)$ & $4,789.0$ & $6,869.1$
\end{tabular}

* Controlled for maternal age, prenatal visits, singleton pregnancy, term pregnancy, vaginal delivery, and maternal schooling.

Odds ratio (OR) for each pollutant, considering exposure during the 90 days prior to birth, in quartiles, with respective $95 \%$ confidence intervals $(95 \% \mathrm{Cl})$ São José dos Campos, São Paulo State, Brazil, 2001 *

\begin{tabular}{lccc}
\hline & SO $_{2}(95 \% \mathrm{Cl})$ & $\mathbf{P M}_{10}(95 \% \mathrm{Cl})$ & $\mathrm{O}_{3}(\mathbf{9 5 \%} \mathrm{Cl})$ \\
\hline Percentile: $<25$ & 1.00 & 1.00 & 1.00 \\
Percentile: 25 to $<50$ & $3.39(1.54-7.53)$ & $0.84(0.42-1.68)$ & $0.95(0.45-2.01)$ \\
Percentile: 50 to $<75$ & $2.89(1.33-6.34)$ & $0.86(0.43-1.71)$ & $1.94(0.97-3.87)$ \\
Percentile: $\geq 75$ & $2.14(0.96-4.82)$ & $0.79(0.39-1.59)$ & $1.18(0.57-2.42)$ \\
\hline * Controlled for maternal age, prenatal visits, singleton pregnancy, term pregnancy, vaginal delivery, and maternal schooling.
\end{tabular}


Final model, considering exposure during the 90 days prior to birth, with respective odds ratios (OR), 95\% confidence intervals $(95 \% \mathrm{Cl})$, and p-values. São José dos Campos, São Paulo State, Brazil, 2001 *.

\begin{tabular}{llll}
\hline & OR & $95 \% \mathrm{Cl}$ & p-value \\
\hline $\mathrm{SO}_{2}$ & 1.30 & $1.02-1.65$ & 0.034 \\
$\mathrm{O}_{3}$ & 1.26 & $1.00-1.58$ & 0.050
\end{tabular}

$\beta_{0}=-1.79$

* Controlled for maternal age, prenatal visits, singleton pregnancy, term pregnancy, vaginal delivery, and maternal schooling.

cies, the mothers were free to circulate around the city, and since the concentrations were considered homogeneous, exposure was considered constant.

Ozone, not usually cited as associated with low birth weight, was identified as increasing the odds of low birth weight in a study in California by Salam et al. 12 including some five thousand full-term newborns from 1975 to 1987.

Unlike other studies $7,8,13,14$, the current study opted to investigate the effects of pollutants after excluding potential confounding factors. The option to study the final weeks of pregnancy was due to the fact that this period shows a major fetal weight gain, representing slightly more than $1,500 \mathrm{~g}$ in final birth weight 11 .

The most important finding in this study, unlike others conducted in Brazil 8,9, was the role of ozone in low birth weight. Meanwhile, the study is consistent with Salam et al. 12, who point to a $40 \%$ increase in the odds of low birth weight. These authors did not identify low birth weight according to the pollutants $\mathrm{PM}_{10}, \mathrm{NO}_{2}$, and $\mathrm{CO}$. They used a single pollutant model, and in the multivariate model, ozone remained significantly associated with low birth weight 12 .

According to the review by Šrám et al. 10, ozone did not affect birth weight. In another study in Brazil by Gouveia et al. 15, ozone showed an inverse association between environmental levels and birth weight. Meanwhile, a study in South Korea showed a slight effect of ozone on birth weight 16 .

The effect of ozone on birth weight may involve inflammatory mechanisms. Pregnancy is accompanied by increased alveolar ventilation.
This hyperventilation results in increased ozone absorption, with an inflammatory response and the release of lipid peroxidation products and cytokines. These factors could affect the placental circulation and jeopardize fetal growth 17 .

$\mathrm{SO}_{2}$ was another pollutant whose values were associated with low birth weight. It has frequently been reported as a risk factor for low birth weight $6,7,13,14,18$. As with other pollutants, the mechanism of action for $\mathrm{SO}_{2}$ is still not well known. It may be similar to that of maternal smoking, possibly through a direct effect of sulfate radicals on the fetus via the placenta or the effects of maternal health, or both mechanisms acting simultaneously. The adsorption of $\mathrm{SO}_{2}$ onto particulate matter $\left(\mathrm{PM}_{10}\right)$ could explain the adverse effect on birth weight via cardiovascular mechanisms involving oxidative stress, inflammation, clotting, altered endothelial function, and hemodynamic responses. Since $\mathrm{SO}_{2}$ is inhaled and maternal lung function in pregnancy involves increased alveolar ventilation, this could affect placental vascular functions and jeopardize fetal growth 17 .

$\mathrm{PM}_{10}$ was not associated with low birth weight, in agreement with the findings by Junger \& Leon 9, Salam et al. 12, and Maisonet et al. 13. Meanwhile, our findings disagree with those of Medeiros \& Gouveia 8 and Bell et al. ${ }^{14}$. Kannan et al. 19 propose mechanisms resulting in low birth weight due to exposure to $\mathrm{PM}_{10}$.

This study has some potential limitations. Some are typical of ecological studies, such as not knowing the mother's real exposure to the pollutants and others, like the lack of information on smoking in pregnancy, a known risk factor for low birth weight. Another potential limitation was the lack of information on maternal weight gain during the pregnancy, maternal height, public versus private prenatal care, and adequacy of nutrient intake. Such information is not included on certificates of live birth, and this gap has been identified in studies performed in Brazil 8,9.

This series did not separate low birth weight infants by sex, since a small number of events were expected, and stratification by sex might have jeopardized the study's statistical power.

Although the time series covered only one year, this did not prove to be a limitation, since it was possible to show the effects of the pollutants sulfur dioxide and ozone on birth weight. Most studies in this area in Brazil have been performed in large cities. The exclusion of other potential risk factors for low birth weight allowed assuming that low birth weight occurred due to the action of environmental pollutants. 


\section{Resumo}

O objetivo foi estimar o papel de poluentes no baixo peso ao nascer numa cidade de porte médio. Foi um estudo ecológico com dados obtidos da Declaração de Nascido Vivo relativos a São José dos Campos, São Paulo, Brasil. Os dados ambientais foram fornecidos pela Companhia de Tecnologia de Saneamento Ambiental (CETESB). Foram incluídos no estudo recém-nascidos a termo, com mães entre 20 e 34 anos de idade, segundo grau completo, sete ou mais consultas realizadas no pré-natal, gravidez única e parto normal, para minimizar o efeito de confusão destas variáveis. Utilizou-se regressão logística para estimar o efeito de cada poluente. Baixo peso ao nascer foi considerado aquele inferior a 2.500g. Foram incluídos 2.529 dados de 2001 que atenderam aos critérios de inclusão (25,6\% do total). Identificamos 99 recém-nascidos (3,95\% dessa amostra) com baixo peso e os poluentes dióxido de enxofre e ozônio como associados ao baixo peso ao nascer. O modelo final foi $\pi(x)=-1,79+1,30\left(\mathrm{SO}_{2}\right)+$ $1,26\left(\mathrm{O}_{3}\right)$. Assim, identificou-se o dióxido de enxofre e ozônio como responsáveis pelo baixo peso ao nascer numa cidade de porte médio do Sudeste brasileiro.

Ozônio; Dióxido de Enxofre; Poluentes Ambientais; Baixo Peso ao Nascer

\section{References}

1. Lin CA, Martins MA, Farhat SCL, Pope 3rd CA, Conceição GMS, Anastácio VM, et al. Air pollution and respiratory illness of children in São Paulo, Brazil. Paediatr Perinat Epidemiol 1999; 13:475-88.

2. Pereira LAA, Loomis D, Conceição GMS, Braga ALF, Arcas RM, Kishi HS, et al. Association between air pollution and intrauterine mortality in São Paulo, Brazil. Environ Health Perspect 1998; 106:325-9.

3. Nascimento LFC, Pereira LAA, Braga ALF, Módolo MCC, Carvalho Jr. JA. Efeitos da poluição atmosférica na saúde infantil em São José dos Campos, SP. Rev Saúde Pública 2006; 40:77-82.

4. Ritz B, Yu F, Fruin S, Chapa G, Shaw GM, Harris JA. Ambient air pollution and risk of birth defects in southern California. Am J Epidemiol 2002; 155: 17-25.

\section{Contributors}

L. F. C. Nascimento participated in all the stages of the study. D. A. Moreira participated in the preparation and analysis of the databases and the discussion.

\section{Acknowledgments}

D. A. Moreira wishes to thank the São Paulo State Research Foundation (FAPESP) for providing a scientific initiation scholarship under grant number 06/59447-0.
5. Committee of the Environmental and Occupational Health Assembly of the American Thoracic Society. Health effects of outdoor air pollution. Am J Respir Crit Care Med 1996; 153:3-50.

6. Bobak M. Outdoor air pollution, low birth weight, and prematurity. Environ Health Perspect 2000; 108:173-6.

7. Wang X, Ding H, Ryan L, Xu X. Association between air pollution and low birth weight: a community-based study. Environ Health Perspect 1997; 105:514-20.

8. Medeiros A, Gouveia N. Relação entre baixo peso ao nascer e a poluição do ar no Município de São Paulo. Rev Saúde Pública 2005; 39:965-72. 
9. Junger WL, Leon AP. Poluição do ar e baixo peso ao nascer no Município do Rio de Janeiro, Brasil, 2002. Cad Saúde Pública 2007: 23 Suppl 4:S588-98.

10. Šrám RJ, Binková B, Dejmek J, Bobak M. Ambient air pollution and pregnancy outcomes: a review of the literature. Environ Health Perspect 2005; 113:375-82.

11. Mongelli M, Biswas A. A fetal growth standard derived from multiple modalities. Early Hum Dev 2001; 60:171-7.

12. Salam MT, Millstein J, Li YF, Lurmann FW, Margolis HG, Gilliland FD. Birth outcome and prenatal exposure to ozone, carbon monoxide, and particulate matter: results from the Children's Health Study. Environ Health Perspect 2005; 113:1638-44

13. Maisonet M, Bush TJ, Correa A, Jaakkola JK. Relation between ambient air pollution and low birth weight in the Northeastern United States. Environ Health Perspect 2001; 109 Suppl 3:351-6.

14. Bell ML, Ebisu K, Belanger K. Ambient air pollution and low birth weight in Connecticut and Massachusetts. Environ Health Perspect 2007; 115:1118-25.
15. Gouveia N, Bremmer SA, Novaes HM. Association between ambient air pollution and birth weight in São Paulo, Brazil. J Epidemiol Community Health 2004; 58:11-7.

16. Ha EH, Hong YC, Lee BE, Woo BH, Schwartz J, Christiani DC. Is air pollution a risk factor for low birth weight in Seoul? Epidemiology 2001; 12: 643-8.

17. Barclay ML. Critical physiologic alterations in pregnancy. In: Pearlman MD, Titinalli JE, editors. Emergency care of the woman. New York: McGraw Hill; 1997. p. 303-12.

18. Lin CM, Li CY, Yang GY, Mao IF. Association between maternal exposure to elevated ambient sulfur dioxide during pregnancy and term low birth weight. Environ Res 2004; 96:41-50.

19. Kannan S, Misra DP, Dvonch JT, Krishnakumar A. Exposures to airborne particulate matter and adverse perinatal outcomes: a biological plausible mechanism framework for exploring potential effect modification by nutrition. Environ Health Perspect 2006; 114:1636-42.

Submitted on 25/Apr/2008

Final version resubmitted on 12/Aug/2008

Approved on 25/Aug/2008 